Dr. Piper broke new ground by measuring the length of long-chain molecules and observing the linear relation between the crystal spacing and the chain-length of aliphatic compounds. Later," first with Francis and Malkin and then with Chibnall, he developed a method of applying such crystal measurements to the quantitative analysis of naturally occurring mixtures of aliphatic compounds, and to the elucidation of the metabolism giving rise to the production of plant waxes. In the First World War, Dr. Piper had a distinguished record with the Sherwood Foresters, with three mentions in dispatches and the award of the Distinguished Service Order.

William Bowie Medal of the American Geophysical Union: Dr. H. U. Sverdrup

THE thirteenth award of the William Bowie Medal of the American Geophysical Union (the oxecutive committee of which is the Committee of Geophysics of the National Research Council) has been made to Dr. H. U. Sverdrup, director of the Norwegian Polar Institute, Oslo. Dr. Sverdrup is noted for a wide range of scientific interests which in the field of oceanography and meteorology are concerned principally with the physical aspects of oceans and the interaction of the sea and the atmosphere. As an explorer he has taken part in two north polar expeditions, namely, in Amundsen's ship Maud (1918-25) and in the Wilkins-Ellsworth submarine Nautilus (1931); at the moment he is directing the Swedish-Norwegian-British expedition in the Antarctic. While on the Maud expedition he did research work on terrestrial magnetism and electricity. One of the conditions of the award of the Bowie Medal is that the recipient must have made outstanding contributions in the advancement of co-operative research in geophysies, and this condition has been amply fulfilled, for Dr. Sverdrup is well known for promoting co-operation between scientific workers and institutions and among nations. During 1936-48 he was director of the Scripps Institution of Oceanography, University of California. The William Bowie Medal was first awarded in 1939 to the late William Bowie, the renowned geodesist and geophysicist, in whose honour it was established.

\section{Ibadan University College, Nigeria}

SIR Sydney Phillipson has been appointed chairman of the Provisional Council of Ibadan University College, Nigeria; Sir Sydney was Financial Secretary in Nigeria during 1945-48, and was a member of the Provisional Council of the College until 1949. He takes over the chairmanship of the College Council from the principal, Dr. Kenneth Mellanby, who has temporarily served in this office since the establishment of the College in 1948. The rapid development of the College during the past three years has imposed increasingly heavy responsibilities on Dr. Mellanby in his dual capacity as chairman and principal, and the new appointment will enable Dr. Mellanby to devote himself entirely to the duties of the principalship. Ibadan University College has now more than 300 degree students and the number will rise to 600 in a few years. It has established faculties of arts, science, medicine and agriculture. The permanent buildings of the College are now under construction, and it is hoped that the work will be completed before 1954. Provision of $\mathfrak{1 \frac { 1 } { 2 }}$ millions for capital expenditure on the College has been made by H.M. Government under the Colonial Development and Welfare Aets.

\section{Sickle-Cell Anæmia}

IN this issue of Nature, two long communications (pp. 929 and 931) and two shorter ones (p. 950) refer to aspects of this active field of inquiry. Other recently published work on the subject can also be mentioned. Itano and Wells have determined the relative concentrations of sickle-cell and normal hæmoglobin among a considerable number of individuals showing sickle-cell trait and anæmia (J. Biol. Chem., 188, 65; 1951). Among 24 individuals showing the trait, the percentage of sickle-cell hæmoglobin varied continuously from about 24 to 45 per cent. Three mild cases of sickle-cell anæmia contained between 5 and 20 per cent of normal hæmoglobin. These results seem to indicate that all shades of variation may exist between the trait and severe anæmia, and suggest that the geneties of the disease may be more complex than has hitherto been supposed. Statistical surveys of the ratios of sickle-cell trait to anæmia may thus have little meaning, since it is impossible to guess the percentage of normal hamoglobin present in any one individual on the basis of purely qualitative blood tests. An electrophoretic survey of the relative concentrations of normal and sickle-cell hæmoglobin. carried out among the members of large African families, may help to clear up some of the contradictions reported by Lehmann. The rarity of sicklecell anæmia in East Africa was recently questioned by Foy, Brass and Kondi (East African Med. $\mathscr{H}$. 28,$1 ; 1951$ ), who report that out of thirteen mothers and infants of the Jaluo tribe whose cells showed sickling, four actually had the symptoms of sickle-cell anæmia. The discovery of foci of sickle-cell anæmia in villages around Lake Copais, a recently drained swamp in Greece, is recorded by Choremis, Zervos, Constantinides and Zannos in The Lancet of May 26, p. 1147.

\section{Overseas Work of the British Council}

IN connexion with the recent cuts in the Exchequer grants to the British Council, the overseas work of the Council requires consideration in relation to the work of other bodies. The B.B.C. foreign services contribute much to the friendly understanding of Britain by other countries, and the protests against the proposal to curtail that work have been as strong and widespread as those at the restriction of the overseas activities of the British Council. Assurance was, indeed, given in the House of Commons on April 9 that, in spite of the economies in the British Council and the B.B.C. foreign services, adequate sums will be available; and on April 11 the Foreign Secretary, Mr. Herbert Morrison, stated that increased provision is now being made for the B.B.C. overseas services. A Supplementary Estimate for $£ 100,000$ is to be presented to prevent the loss to the Corporation of the 'channel-hours' now in use for broadcasting to Europe.

This response to opposition in Parliament and in the Press to the reductions earlier announced in Treasury grants for overseas broadcasting ignores, however, the fundamental issue as to how broadcasting of this character should be administered, and its relation to other activitius designed to promote the understanding of the British point of view. Furthermore, there is the technical point, which Mr. John Coatman has raised in correspondence in the Manchester Guardian of April 18, as to how far the objectives of overseas broadcasting are achieved by the present practice, on which at present some $£ 11,000,000$ is expended. He himself is convinced that British 